\title{
ACCESS TO SOCIAL RIGHTS AND PERSONS WITH DISABILITIES
}

Nino ŽGANEC, Maja LAKLIJA, Marina MILIĆ BABIC Faculty of Law, Zagreb

UDK: 364.013-056.26(497.5) $342.734-056.26(497.5)$ $351.84-056.26(497.5)$

Pregledni rad

Primlieno: 1. 10. 2010.

The issue of access to social rights of persons with disabilities is part of the wider area of regulation of social rights in the contemporary world. The past fifty years were marked by significant progress in the establishment of social rights not only as possibilities and intentions, rather as a real contribution to raising the quality of life. This article has the following goals: to analyze the existing legislation concerning recognition of social rights of persons with disabilities in Croatia, including some elements of the functioning of the systems responsible for access to social rights for persons with disabilities; to outline some characteristics of the reforms carried out in the most important "social systems" in Croatia (social welfare, education, health care, pension and employment system); to establish the level of perceived accessibility of some social rights for their beneficiaries and the level of the expressed need for individual forms of social rights. The results of the study illustrate some trends and possible problems that people with disabilities face in accessing or attempting to access certain social rights.

Keywords: social rights, persons with disabilities, social policy, access to social rights

$\triangle$ Nino Žganec, Faculty of Law, University of Zagreb, Department of Social Work, Nazorova 51, 


\section{INTRODUCTION}

\section{The Origin, Concept and Notion of Social Rights}

In the past fifty years, throughout the world - and, particularly, across Europe - we have witnessed a progress being achieved in the introduction and promotion of social rights. In 1961, the Council of Europe passed the European Social Charter, thus indicating that social rights were to constitute the backbone of the efforts for achieving social cohesion in the European Union (EU) and that the Council itself were to play a major role in establishing a general code of economic and social rights (Daly, 2002). The development of social rights as an institutionalized form of social security of citizens has been gradual. As Marshall (1994, according to Puljiz, 2004, 4) points out, "Western Europe first saw the emerging of civil rights (in the 18th century), then political rights (in the 19th century) and, eventually, social rights (in the 20th century). "Social rights" is not an unambiguous notion because numerous interpretations are used in its definition. However, since we are talking about rights, it is usually interpreted as "provisions contained in laws or in other forms, enabling fulfillment of people's social needs and promotion of social cohesion and solidarity; social rights include social protection, housing, employment, health care and education" (Daly, 2002, 15). Sajo (2005) points out that there is a "significant flexibility" in the use of the term "social rights", with national legislations and numerous international documents being conducive to it, while application of codified law in different countries has resulted in various practices and traditions.

The European Social Charter and its Additional Protocol of 1988 guarantee fundamental rights, among which the rights of employees, rights of all members of a state and rights of certain groups (women, mothers, families, migrant workers and elderly) to a special protection outside labor relations can be singled out. The Revised Social Charter of 1996 also contains a series of new rights, such as the right of the elderly to social protection, right to protection from poverty and social exclusion and right to suitable housing at an acceptable price. One of its most important characteristics is the introduction of the concept of social rights as an obligation of the state and not as individual rights. This means that states are obliged to provide funds and mechanisms for undisturbed access to social rights and eliminate possible obstacles to such access. Moreover, states are expected to ensure continual improvement of standards in the area of social rights through the so-called "successive evaluation" procedure.

Besides the European Social Charter, the 1989 Charter of the Fundamental Social Rights of Workers and the adoption 
DRUŠ. ISTRAŽ. ZAGREB GOD. 21 (2012), BR. 1 (115) STR. 59-78

ŽGANEC, N., LAKLIJA, M., MILIĆ BABIĆ, M.: ACCESS TO SOCIAL. of the EU Charter of Fundamental Rights in 2000 have also made a considerable contribution to the establishing of social rights in the EU.

Certainly, one of the most important characteristics of social rights is the presumed active and binding role of the state. By accepting social rights, the state guarantees its citizens that it will play an active role in financing and organizing services that will make social rights accessible on the central and local levels. This is what makes social rights different from civil or political rights because of their free exercise without the "interference" of the state. Further, while civil and social rights are considered absolute and immediate, social rights depend on the possibilities of a society in a given moment. Such a characteristic has contributed to the justifiability of civil and political rights on one hand and to the unactionability of some social rights on the other (particularly those social rights which are exercised on the basis of the discretion assessment of social services, e.g. social assistance) (Puljiz, 2004). The fact that a considerable number of verdicts in the area of social rights can be found in the European court practice is an indication of increased awareness of their importance not only for the creation and maintaining of social cohesion, but also for the economic stability and prosperity of modern societies. Besides in the above mentioned fundamental documents, the development of social rights can also be traced on a wider international level, particularly in the work of such international bodies as the UN, ILO, WHO and others. From the 1948 General Declaration on Human Rights to international treaties on civil, political, economic, social and cultural rights, social rights are becoming more and more focused on the protection of "vulnerable" social groups such as children, the elderly, persons with disabilities, women and others.

\section{Social Rights of Persons with Disabilities}

It is estimated that there are around 600 million persons with disabilities in the world, accounting for some $10 \%$ of the world population. When we talk about persons with disabilities, it should be mentioned they are not a homogenous, but very heterogeneous group in terms of the type or degree of disability and various distinguishing categories. Equally varying are the definitions of disability, which lead to different estimates of the number of persons with disabilities (ranging from 8 to $14 \%$ of the population in the EU countries). According to the 2001 census, there are 429,421 registered persons with disabilities in Croatia, accounting for $9.6 \%$ of the country's population. According to the definition of the Council of Europe (1992, Article 3), disability is a "limited ability caused by phy- 
DRUŠ. ISTRAŽ. ZAGREB BR. 1 (115),

STR. $59-78$

ŽGAN̦EC, N, LAKLIJA, M. MILIĆ BABIĆ, M. GOD. 21 (2012), ACCESS TO SOCIAL.

sical, psychological, sensory, social, cultural or other hindrances preventing persons with disabilities from being integrated and from participating in the life of family and community on the same bases as everyone else". Taking into account the Joint Report on Social Inclusion (European Commission, $2002,10-11)$, we can talk about the "state of disability", where "disability represents one of the factors exposing people to the risk of poverty or situations in which they cannot fully participate in economic, social and political life".

Persons with disabilities should have rights and obligations equal to those of the remaining population; however, some of their rights have not been ensured, so their participation in social and public life is limited. States should, therefore, take action to equalize their rights with the rights of others and increase the community's awareness of persons with disabilities, focusing on their rights and needs, but also on their potentials. In accordance with the above, the UN, Council of Europe and EU recommend that their members should establish international cooperation in equalization of opportunities for persons with disabilities on global and regional levels. However, the most important of them is the 2007 Convention on the Rights of Persons with Disabilities.

Through its Constitutional Provisions and a series of laws and special programs, the Republic of Croatia has paid particular attention to the protection of social rights of persons with disabilities. Thus, the Croatian Constitution emphasizes that the state shall dedicate special concern to the protection of persons with disabilities and their inclusion into social life. It also mentions the right of physically and mentally challenged and socially neglected children to special care, education and provision, as well as the right of youth, mothers and persons with disabilities to special protection at work. The Republic of Croatia has also expressed its concern about persons with disabilities by ratifying the Convention on the Rights of Persons with Disabilities only a year after its adoption by the UN General Assembly.

\section{Financing of Social Rights}

Since social rights require a more active role of the state in organizing services and sources of financing required for their provision, such funds are planned in the state budget and local budgets and are collected through taxes and contributions. Sjoberg (1998) points out that, in the period from 1960 to 1993, transfers in the area of social security were increased from 7 to $16 \%$ of GDP in the OECD countries. The growth of social expenditure in those countries reflects the so-called "revolution in growth of rights". The raising of standards of pro- 
DRUŠ. ISTRAŽ. ZAGREB GOD. 21 (2012), BR. 1 (115) STR. 59-78

ŽGANEC, N., LAKLIJA, M., MILIĆ BABIĆ, M. ACCESS TO SOCIAL. tection of social rights has led to increased social security of citizens, but also to increased cost of labor and total expenditure that society is "spending" on the social sphere (Sjoberg, 1998). In the past two decades, the financing of social rights has therefore come under pressure of the growing economic competition in the globalized world. The business sector has been exerting more and more pressure on the governments to reduce social expenditure and cost of labor and production. This is a trigger for social reforms that have to focus on the issue of further sustainability of the financing of social rights. The trends arising here are directed towards privatization or transferring of a part of social insecurity from state to an individual (Puljiz et al., 2005). Esping-Andersen (1990) talks about processes of decommodification, that is, reduction of citizens' dependence on market with assistance of state. However, as Puljiz et al. $(2005,162)$ point out, "the social reforms that have been taking place in the past period, which are characterized by a cost-reduction policy, have the opposite direction. We can call them recommodification in social policy". Recommodification means an increased dependence on market, increased individual responsibility and decreased social redistribution carried out by state. There is much talk about the need for decentralization of financing and governance, particularly in the countries with socialist legacy and highly centralized social services. Moreover, financial problems have in the past years led to new challenges in the financing of social rights and protection of individual social groups.

\section{Access to Social Rights}

The dynamic development of social rights is connected with the raising of the social security of citizens, but also with the challenges reflected in the barriers to their access to social rights. As Daly $(2002,33)$ points out, "barriers appear along the entire chain of social rights, from the form or declaration of rights to the processes, procedures and resources required for their realization to the situation of a beneficiary or potential beneficiary who is trying to exercise such rights". Besides, formal recognition of some social right does not necessarily guarantee its implementation in practice (Duffy, 1998). Numerous documents have not only a positive role, reflected in promotion and guaranteeing of social rights, but also a negative one that can be characterized as normative optimism or an endless list of rights that can rarely be realized to the full extent. Furthermore, it seems that obstacles sometimes constitute an integral part of the system of protection of social budget from abuse by its beneficiaries and their large number indicates the need to create well laid out service-providing systems, as is argued 
DRUŠ. ISTRAŽ. ZAGREB GOD. 21 (2012),

BR. 1 (115),

STR. $59-78$

ŽGANEC, N, LAKLIJA, M. MILIĆ BABIĆ, M.:

ACCESS TO SOCIAL. by the "integrated social services" concept (Munday, 2010). It should be noted here that growing negative and challenging attitudes toward social rights show neoliberal influences and tendencies that directly contradict the concept of social cohesion. This gives an exceptional importance to the efforts that the Council of Europe makes by encouraging projects directed toward the strengthening of social cohesion and building of a European social model that accepts the viewpoint that "economy cannot function in a social vacuum, so the basic goal of the strengthening of social rights is to reduce social and political differences and perturbations" (Daly, 2002, 27).

\section{THE GOALS}

Taking as a starting point the attitude of the Council of Europe (Daly, 2002, 31) that the "access to social rights depends on: a) the expression, structural frame or form of rights; b) the process and procedures of efficient realization of rights or available resources for their realization, and c) situation, including the capability and available resources of potential holders of rights", this article has the following goals:

1) To analyze the existing legislation concerning recognition of social rights of persons with disabilities in Croatia, including some elements of the functioning of the systems responsible for access to social rights for persons with disabilities;

2) To outline some characteristics of the reforms carried out in the most important "social systems" in Croatia (social welfare, education, health care, pension and employment system);

3) To establish the level of perceived accessibility of some social rights for their beneficiaries and the level of the expressed need for individual forms of social rights.

\section{THE METHODOLOGY}

To achieve these goals, we will analyze the documents, primarily laws, national programs, strategies and reform-related documents. When establishing the level of accessibility of certain social rights for their beneficiaries, we will present the results of the survey that was conducted from December 2008 to December 2009 by the Department of Social Work at the Faculty of Law in Zagreb and Ministry of Family, Veterans' Affairs and Intergenerational Solidarity (MFVAIS). From a large set of variables contained in the Questionnaire for Persons 
DRUŠ. ISTRAŽ. ZAGREB GOD. 21 (2012), BR. 1 (115) STR. 59-78

ŽGANEC, N., LAKLIJA, M., MILIĆ BABIĆ, M.: ACCESS TO SOCIAL. with Disabilities, ${ }^{1}$ we have singled out those that are relevant to the area of social rights. ${ }^{2}$ The respondents who filled out the Questionnaire had to answer if they had used any of the forms of assistance and/or services offered $(1=\mathrm{No}, 2=$ Yes, before and $3=$ I receive). They also had to say what forms of assistance they considered the most necessary (open question). The data were weighed by gender, age and education variables. The sample is structured as a probabilistic one and it comprises 391 adult persons with disabilities, of whom $49 \%$ are women and $51 \%$ are men. For a detailed description of the sample and methodology, see Leutar and Buljevac (2012).

In line with the goals that have been set, we will present an overview of the social rights of persons with disabilities envisaged either by special programs or by legal provisions and will take a look at some characteristics of the functioning of the reform of systems responsible for ensuring access to social rights and the challenges that this functioning is facing. As an illustration, we will link them with the results of the above mentioned survey.

\section{OVERVIEW OF SOCIAL RIGHTS OF PERSONS WITH DISABILITIES IN SOCIAL POLICY SYSTEMS IN CROATIA}

\section{Social Welfare}

\footnotetext{
1 The authors of this questionnaire are Ph.D. Zdravka Leutar and Marko Buljevac.

2 We thank prof Leutar and colleague Buljevac who provided us with research database.
}

Under the law, social welfare is an activity of special interest for Croatia, ensuring and bringing about the assistance for fulfillment of the basic necessities of life of the socially vulnerable, feeble and other persons who cannot fulfill such necessities on their own or with the help of their families due to unfavorable personal, economic, social or other circumstances (Potočnjak and Vukorepa, 2007). Through the social welfare system, citizens are guaranteed fundamental security in terms of a social-protection network sensitive to the risks that can lead to deterioration of social, health or economic status. Social welfare activities have a key role not only in rehabilitation of the consequences of unfavorable living conditions, but also in prevention of situations that could affect social welfare. They have an important role of special state concern, underlined in the Constitution, for the protection of persons with disabilities and their inclusion into social life, as well as of families, children and other persons (The Constitution of the Republic of Croatia, 2001). The social welfare system was established by the 1997 Act which, after its specific implementation in wartime conditions, was amended to include the principles of subsidiarity, humanization, equality and solidarity (Učur, 2000). Some of the most important rights that persons with disabilities can exercise within the social welfare sy- 
DRUŠ. ISTRAŽ. ZAGREB GOD. 21 (2012), BR. 1 (115),

STR. $59-78$

ŽGANEC, N., LAKLIJA, $M$. MILIĆ BABIĆ, M. ACCESS TO SOCIAL. stem include the right to assistance- and carer-allowance, right to house-care allowance, right to personal disability allowance, right to become fit for independent living and work, right to a care outside one's family and right to the parent-caregiver status (the latter being a newly introduced right that can be exercised by parents of children with serious disabilities). The above mentioned rights are related to persons with disabilities who, if statutory conditions are met, can also become beneficiaries of other rights from the social welfare system (e.g. counseling, one-time payments). Further, the Social Welfare Act sets forth the specific categories of social welfare beneficiaries: physically or mentally challenged children or adults, or children or adults with psychic diseases, elderly people and other persons who, due to permanent or temporary changes in their health condition, cannot satisfy their basic necessities of life. Social welfare activities are being carried out through a relatively widespread network of social services (social welfare centers), institutions and homes that provide services of permanent, weekly, day, or occasional care or organized housing. In the past decade, the Act has been amended several times and novelties have been introduced to the system of the rights of persons with disabilities, trying at the same time to raise standards and meet the needs that such persons have. While these, relatively frequent amendments to the Act have led to certain improvements in the access to social rights, they have also created new obstacles that the earlier mentioned report of the Council of Europe categorizes as belonging to the type of obstacles called "defining of rights and adequacy of legal and other measures of their implementation", "management and procedures" and "information and communication".

In the context of access to social rights for persons with disabilities, education has a central role in making citizens fit to become full-fledged participants of life in the community and contributes to elimination of obstacles in access to social rights. Thus, the European Convention on Human Rights that emphasizes the right to education as a fundamental right of children and adolescents has been followed by many other documents emphasizing the right of developmentally challenged children to education. The same applies to the Convention on the Rights of the Child and European Convention on the Exercise of Children's Rights. The Croatian Constitution protects the rights of developmentally challenged children by establishing their right to special care, education and welfare. The measures and activities that should follow the targeted 
DRUŠ. ISTRAŽ. ZAGREB GOD. 21 (2012), BR. 1 (115) STR. 59-78

ŽGANEC, N., LAKLIJA, M., MILIĆ BABIĆ, $M$. ACCESS TO SOCIAL.

\section{Health Care}

policy in the education system and the new ones that will ensure the rights of developmentally challenged children and persons with disabilities and improve and equalize the quality of the entire system were defined by the National Strategy of Equalization of Opportunities for Persons with Disabilities 2007-2015, brought into line with the Education Sector Development Plan 2005-2010, Development Strategy of the Vocational Education System in the Republic of Croatia 2008-2013 and the National Plan of Activities for the Rights and Interests of Children 2006-2012, as well as with relevant international documents. The 2008 Primary and Secondary Education Act contains the principles of non-discrimination in access to education and mentions developmentally challenged students while making a distinction between some categories of students. Special regulations identify the types of difficulties based on which a student is entitled to appropriate programs, special curriculum and special types of education. The Act reflects the legislator's intention to make a shift to so-called integrated education and gradual abolishing of the dual education system. In the context of respect for human rights, the problem lies in the fact that the education of certain categories of developmentally challenged children is taking place in educational units of the institutions functioning within the social welfare system - called education centers, currently attended by more than 1,600 developmentally challenged children and adults (Ministry of Health and Social Welfare, 2009). Since they have to ensure education for their children, the parents are forced to accept such a form of education. However, in the long run, this system is untenable and should undergo radical changes. The Act on Scientific Activity and Higher Education (2009) has no special provisions on the rights of students with disabilities; this area has been left to the autonomy of the university. Still, the modifications of the legislative framework indicate that progress has been made in acquiring a systematic approach to ensuring social rights of the developmentally challenged children and students in the science and education system.

The rights and obligations of persons covered by compulsory health insurance are ensured on the basis of mutuality and solidarity, as provided by the Compulsory Health Insurance Act and Rules on Rights, Conditions and Realization of Rights Arising from Compulsory Health Insurance. The services included in primary health care, particularly important for persons with disabilities, certainly include house calls and home care which is provided in order to improve the health condi- 
DRUŠ. ISTRAŽ. ZAGREB GOD. 21 (2012), BR. 1 (115)

STR. $59-78$

ŽGANEC, N., LAKLIJA, M. MILIĆ BABIĆ, M. ACCESS TO SOCIAL... tion of a patient and to prevent its deterioration. The right to home care can be exercised if the following conditions have been established: immobility/lower mobility; a deteriorating chronic disease or complications that have appeared; and transient or permanent conditions after complex operations that patients cannot take care of on their own. Domiciliary care and transport by ambulance for special categories of insurees should also be mentioned here. In addition to hospital care, it is also important to mention hospital treatment using physical therapy at home. Insurees are also entitled to: sickness benefit during temporary incapacitation/being unable to work due to a treatment or during other circumstances specified by the Act; pecuniary compensation for being incapacitated to perform job tasks in accordance with regulations on compulsory health insurance contributions; and transportation bonus.

\section{Pension Insurance}

Under the Pension Insurance Act, provided that statutory conditions have been met, persons can exercise their right to a) old-age pension; b) early-retirement old-age pension; c) disability pension (due to general inability to work or professional inability to work); d) survivor's pension; e) minimum pension; f) basic physical-impairment allowance, professional rehabilitation and, in connection with that right, the right to personal income compensation, traveling allowance (in connection with exercise and use of the rights from pension insurance and professional rehabilitation) and pension supplement for pensions earned under the Pension Insurance Act. In order to become entitled to a disability pension, the conditions concerning disability and years of service for retirement must be met. Disability can occur as a result of a disease, injury outside/at work or occupational disease. A person is considered to have disability when, due to changes in his/her health that cannot be eliminated by medical treatment, the working ability of such a person is permanently reduced by more than a half compared to a healthy person of similar education and ability. When professional inability to work has been established in an insured person, the remaining working ability must then be established if such person, given his/her health condition, age, education and ability, can be made fit for a different full-time job by means of professional rehabilitation. The condition of years of service is met when the length of service for retirement covers at least one third of working life, if the disability has occurred due to a disease/injury outside work before the age of 65 . However, the law envisages exceptions. If the disability has occurred due to an injury at work 
DRUŠ. ISTRAŽ. ZAGREB GOD. 21 (2012), BR. 1 (115) STR. 59-78

ŽGANEC, N., LAKLIJA, M., MILIĆ BABIĆ, M.: ACCESS TO SOCIAL.

\section{Employment}

or occupational disease, the right to a disability pension is acquired regardless of the length of service for retirement. Disability/physical impairment/general inability to work is established by the authorized unit of the Institute on the basis of expert assessment. The right to physical impairment compensation is acquired in case of an impairment of at least $30 \%$, resulting from an injury at work or occupational disease. Very important is also the right to professional rehabilitation.

The right to children's allowance is provided by the Children's Allowance Act. Under the social welfare regulations, children with severely impaired health are entitled to an allowance in the amount of $25 \%$ of the budgetary base, regardless of the amount of the total monthly income per household member. Also, children whose health was severely impaired before the age of 18 are entitled to the allowance by the end of the calendar year in which they turn 27 years of age.

According to the Croatian Employment Service (CES) statistics, 6,125 persons with disabilities were registered there at the end of 2009 (accounting for $2.13 \%$ of the total number of registered persons) (CES, 2010). In 2009, there were 472 persons with disabilities who made professional inquiries and 1,644 took part in professional counseling (412 attended individual counseling sessions and 1,232 attended group sessions). In accordance with the Act on Professional Rehabilitation and Employment of Persons with Disabilities (OG, 143/02, 33/05) and the measures of the National Strategy of Equalization of Opportunities for Persons with Disabilities 2007-2015, the Institute has been participating in the active policy measures in co-financing of employment and stimulation of integration into the labor market of persons in unfavorable conditions, that is, special groups of unemployed persons that also include persons with disabilities. With mediation of the CES, which provided support in the form of co-financing employment, 1080 persons with disabilities were employed in 2010 (CES, 2011). In 2009, 23 persons with disabilities were included in education and 107 in public work programs (CES, 2010, 33). Since 2009, CES, the City of Zagreb, URIHO and Fund for Professional Rehabilitation and Employment of Persons with Disabilities have been cooperating on establishing a "Working Center" as a new model of professional rehabilitation and employment of the long-term unemployed persons with disabilities. The "Employer of the Year for Persons with Disabilities" Project has also been launched in order to stimulate their employment. The "Encouraging of More Intensive Integration into Labor Market of Persons with Disabilities" Project (a part 
of the Instrument for Pre-accession Assistance program) is being implemented at the moment in order to improve social inclusion of persons with disabilities and stimulate their integration into the labor market (CES, 2010).

\section{Comments on the Survey Results}

The results of the survey that has been carried out (Tables 1 and 2) show what types and forms of social rights are most frequently used by persons with disabilities and what kinds of rights they consider to be the most important. The obtained results draw our attention to the respondents' focus on financial forms of assistance. That is not so unexpected because their disability often makes it more difficult for them to find employment, thus often leading to poverty and social exclusion (UNDP, 2007). Thus, the respondents claim that, of the rights from the social welfare system, they mostly use the assistance- and carer-allowance, personal disability allowance and one-time payments; of the rights from the pension insurance system - children's allowance; of the rights from the health-care system - exemption from co-payment and orthopedic aids. Of the rights from the education system, they intensely use the right to free textbooks and the right to accommodation in students' dormitories. Of other rights, we can single out the right to fare reduction in public transport. Due to the specific nature of the Questionnaire, the fact that the right to use individual types of assistance is specified to detail by the law, and the indicators we did not have access to on the basis of the instrument used, it would not be justified to generalize the results on the basis of some complex methodological analyses. Further, when asked what types of assistance they needed the most, the majority of the respondents said it was financial assistance, followed by practical assistance, adequate/available health care and psychological assistance/ counseling. According to the UNDP (2007), people with disability are still invisible in the community and are not largely integrated into the social fabric. A substantial amount of research, as well as measures of state institutions, have confirmed that discrimination against the disabled persists in all areas of social fabric (education, health, social welfare, employment, housing, environment and public life).

\section{SOME CHARACTERISTICS OF THE REFORMS CARRIED OUT IN THE SYSTEMS RESPONSIBLE FOR ACCESS TO SOCIAL RIGHTS FOR PERSONS WITH DISABILITIES}

Although it is possible to discuss the social rights of persons with disabilities in their present form in the context of the above mentioned documents, in wider terms they nevertheless follow the concept of the social state that emerged in the 
DRUŠ. ISTRAŽ. ZAGREB GOD. 21 (2012), BR. 1 (115) STR. 59-78

ŽGANEC, N., LAKLIJA, M. MILIĆ BABIĆ, M.: ACCESS TO SOCIAL.. 19th century as an "extension of the classical protector-state" (Puljiz et al., 2005, 23). Under the challenges of globalization that is bringing along the growing international competition in economy and in other sectors of society, systematic social reforms have been launched. As Bonoli and Palier (1998) point out, the first wave of social state reforms that took place in the UK and U.S. in the 1980s and in continental Europe in the 1990s left most of the social protection systems rather intact. However, some of the reforms that had been carried out created possibilities for the reforms in the late 1990s. When discussing reforms and decentralization, Kissane (2006), points out that reforms are implemented for various reasons and that local authorities are more skilled in providing assistance to families in need than the central government because they are better connected and more aware of local people's problems. Discussing privatization in the area of social protection, Pearson and Martin (2005) point out that public expenditure in the 29 OECD countries has reached some $43 \%$ of the GDP. Since social expenditure accounts for one half of this expenditure, the private sector's more intense penetration to the area of social protection services is being considered. Past experience with this diversification of service providers has resulted in the following conclusions: a) creating opportunities for private service providers is linked with the possibility of wider choice and innovation, and b) efficiency in final gains is limited due to rising prices of services and high tax incentives for private service providers that are required. Discussing the main trends in social reforms, Bonoli et al. (2000, according to Puljiz et al., 2005) emphasize two main trends: the trend of privatization and the trend of transferring part of the social insecurity from the state to the individual. In addition, pressures on the social sphere, which are reflected on the level of international economic competition, lead to globalization of social policies and the creation of a European social model.

Although reforms in health care, pension and other social policy systems in Croatia started as early as in the wartime and post-war conditions of the 1990s, in order to establish a system based on ethical and expert principles, the systematic reforms of social policy began in the 2000s (Puljiz and Žganec, 2002). As one of the largest social-policy systems in Croatia, the pension system "has the function to be used by individuals and their families as a mechanism that will enable them to distribute expenditure across their lifetime, particularly after their working life, in case of disability or loss of a provider, that is, when insurees and those supported by them cannot work for a living any more" (Puljiz, 2007, 164). The rights 
DRUŠ. ISTRAŽ. ZAGREB GOD. 21 (2012), BR. 1 (115),

STR. $59-78$

ŽGAN̦EC, N, LAKLIJA, M. MILIĆ BABIĆ, M. ACCESS TO SOCIAL... that persons with disabilities can exercise within the pension system have been jeopardized because of the crisis of that pension system caused by negative demographic trends, the economic situation, the aftermath of war and, also, a bad pursuit of the pension insurance policy. The early 2000s witnessed the beginning of a large-scale pension reform that was supposed to contribute to stabilization of the system and enable financing of the pension insurance rights. As Puljiz $(2007,182)$ points out, at the very beginning of the reform, "harder conditions for disability retirement were laid down and the procedure of assessment of disability was changed, too. In addition to general disability, professional disability was introduced, as well." The numerous solutions that followed as part of the pension system reforms (e.g. introduction of the second and third pillars of insurance) did not substantially improve the access to the rights for persons with disabilities. For this reason, despite some undeniably positive results of the reforms carried out so far (the stabilization effect), further reforms aiming to maintain the system can be expected.

As for the health care system, in the opinion of the European Observatory on Health Care Systems (1999, according to Zrinščak, 2007) Croatia entered the 1990s with a dysfunctional, poorly organized and expensive health care system which needed thorough reconstruction. This was the reason why several reforms have been carried out - in 1993, 2000 and 2006. The latter one is still ongoing and its concept can be found in the document called the National Development Strategy for Health Care 2006-2011. As Zrinščak $(2007,205)$ points out, the 2006 reform "tried to devise an integral vision of health care and also to find a prompt solution for its most urgent financial problems". The reforms that have so far influenced the rights of persons with disabilities have had a limited positive effect which, among other things, is reflected in the extended list of free drugs, reduced waiting lists for specialist and consulting services and improvements in the orthopedic aid procurement system. However, the accumulated problems (financing, inadequate health-care coverage of certain areas, unsatisfactory ratio of medical staff etc.) constitute substantial barriers to exercising of rights. In the reforms which are to follow, particular attention will have to be paid to it.

Reforms in the education system in the past few years have contributed to a better-quality access to social rights for persons with disabilities. Thus, the 2006 primary school curriculum envisages flexible contents and forms of work that would fit integrated education of developmentally challenged schoolchildren. Also, under the laws on primary and secondary education, classes at home are provided for the school- 
DRUŠ. ISTRAŽ. ZAGREB GOD. 21 (2012), BR. 1 (115) STR. 59-78

ŽGANEC, N., LAKLIJA, M. MILIĆ BABIĆ, $M$. ACCESS TO SOCIAL. children who are not able to attend classes in school due to their condition. The Development Strategy for Vocational Education System in Croatia 2008-2013 was passed and the Agency for Vocational Education and Agency for Adult Education were strengthened. Implementation of a law on adult education is expected (Commission of the European Communities, 2008). Education of primary-school students with developmental difficulties is taking place in primary schools with full or partial integration, depending on the degree and type of difficulties. While progress has been made in access to the rights in education, some issues have remained open: existence of the dual education system, ill-prepared regular system for acceptance of children with developmental difficulties, teachers' competence to work with them, and insisting on the concept of integration of children with developmental difficulties into the regular education system instead of supporting a more adequate concept of inclusion for this student population.

The reforms in the employment system and protection of the unemployed are outlined in the National Employment Action Plan 2005-2008, which is the first national plan of this kind. Based on the Joint Memorandum on Priorities of the Employment Policy prepared by the Croatian Government and General Directorate for Employment of the European Commission, preparation of the Annual Plan for Stimulation of Employment is envisaged. The Plan will deal with social issues and equal opportunity issues. The Croatian Government has enacted Annual Plans for 2007 and 2008, as well as the National Plan for Stimulation of Employment 2009-2010, which includes measures for stimulation of entrepreneurship, cooperatives, co-financing of employment, education and self-employment. The measures are directed toward employment and education of long-term unemployed persons, young persons without working experience, the elderly, and those with lower qualifications in order to help them acquire the skills and knowledge which are in demand on the labor market. Furthermore, a part of the operational measures would be focused on promoting integration and the fight against discrimination against persons who are in an unfavorable position on the labor market. The Act on Professional Rehabilitation and Employment of Persons with Disabilities (2002) was supposed to give substantial impetus to the employment of persons with disabilities; however, the results of its implementation have been inadequate.

In 2005, the Ministry of Health and Social Welfare, which is responsible for preparation and implementation of the social welfare reform in Croatia, introduced a new structure 
DRUŠ. ISTRAŽ. ZAGREB GOD. 21 (2012) BR. 1 (115),

STR. $59-78$

ŽGAN̦EC, N, LAKLIJA, M. MILIĆ BABIĆ, M.: ACCESS TO SOCIAL... of the system reform project. This project pays much more attention to investments in physical infrastructure (construction and hygienic-sanitary conditions of accommodation) than to investments in restructuring of business processes. This leads to delays in reorganization of the contents of the social services system. As a result, important amendments to laws are not being carried out. Only in the past year and a half certain progress could be seen in preparation of amendments to the legislation (some crucial bills are being submitted to public discussions now) and in introduction of a system of quality, standards and information technology that should contribute to a future system that will function better and provide services available to all.

\section{CONCLUSIONS}

The passing of the European Social Charter has placed the issue of social rights into the focus of social interest. As a result, the issue of citizens' access to social rights has become much more intensive in the past decade. Persons with disabilities constitute a group which, due to their special characteristics, needs additional engagement and special attention in policy-making in all social-policy systems. Despite numerous solutions in national legislations, international legislation and numerous special programs, the access of persons with disabilities to various social rights requires additional attention in most countries. Croatia is not an exception here: while it has made undeniable progress in guaranteeing social rights to persons with disabilities, many other activities and areas are yet to be improved or designed. The results of the survey indicate that financial problems are on the top of the list of priorities of persons with disabilities. This partly suggests that they lack means of subsistence and have access to/are familiar with, too few social and other services in the community that, if available to them, could reduce their considerable need of financial sources. This situation suggests that improvements and reforms are required in various social security systems. They would make the guaranteed social rights really available to those for whom they have been designed. Although the current economic situation in the world seriously hinders the improvements of the social policy system, it is encouraging that the EU countries and most of the important international organizations are starting to see social payments as an investment, not as spending. The results of such tendencies can clearly be seen in numerous improvements of the position of persons with disabilities, primarily in terms of legislation. It is to be expected that, in the period to come, improvements will also be visible in the actual access to social rights. 


\section{ANNEX}

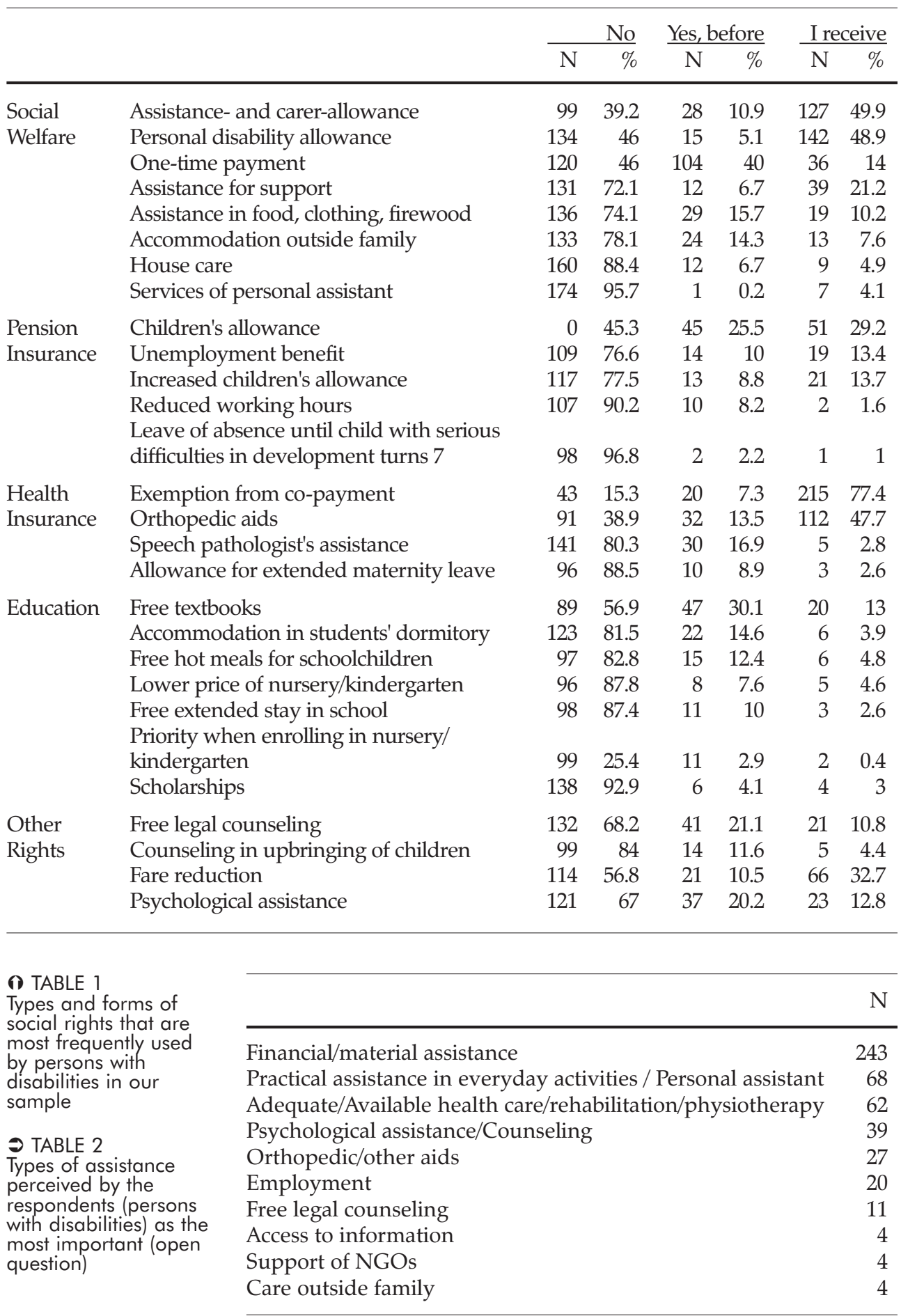


Act on Professional Rehabilitation and Employment of Persons with Disabilities. Official Gazette No. 143/02, 33/05.

Act on Scientific Activity and Higher Education. Official Gazette No. 45/09.

Bonoli, G. and Palier, B. (1998), Changing the Politics of Social Programmes: Innovative Change in British and French Welfare Reforms. Journal of European Social Policy, 8 (4): 317-330. doi:10.1177/095 892879800800403

Children's Allowance Act. Official Gazette No. 94/01, 138/06, 107/07.

Commission of the European Communities (2008), Croatia 2008 Progress Report, Brussels, Commission of the European Communities.

Compulsory Health Insurance Act. Official Gazette No. 158/08.

Council of Europe (1992), Council of Europe Parliamentary Assembly Recommendation 1185, Council of Europe.

Croatian Bureau of Statistics (2001), Census 2001, http://dzs.hr (11. 09. 2010)

Croatian Employment Service (2010), Godišnjak 2009 (Yearbook 2009), Zagreb, Hrvatski zavod za zapošljavanje (Croatian Employment Service).

Croatian Employment Service (2011), Report on the Activities of the Croatian Employment Service in the Employment of People with Disabilities in the Period from 01 January to 31 December 2010, Zagreb.

Daly, M. (2002), Access to Social Rights in Europe, Strasbourg, Council of Europe.

Duffy, K. (1998), The Human Dignity and Social Exclusion Project: Opportunity and Risk Trends of Social Exclusion in Europe, Strasbourg, Council of Europe.

Esping-Andersen, G. (1990), The Three Worlds of Welfare Capitalism, Cambridge, Polity Press.

European Commission (2002), Joint Report on Social Inclusion, Brussels, Directorate General for Employment and Social Affairs.

European Convention on Human Rights. Official Gazette No. 6/99.

Government of the Republic of Croatia (2004), National Employment Action Plan 2005-2008.

Government of the Republic of Croatia (2007), Annual Plan for Stimulation of Employment for 2007.

Government of the Republic of Croatia (2008), Annual Plan for Stimulation of Employment for 2008.

Government of the Republic of Croatia (2009), National Plan for Stimulation of Employment for 2009-2010.

Kissane, R. J. (2006.), Responsible but Uninformed? Nonprofit Executive and Program Directors Knowledge of Welfare Reform. Social Service Review, 80 (2): 322-345. doi:10.1086/501490

Leutar, Z. and Buljevac, M. (2012), Zaposlenost osoba s invaliditetom u Hrvatskoj i zemljama Europske unije (Employment of People with 
DRUŠ. ISTRAŽ. ZAGREB GOD. 21 (2012), BR. 1 (115) STR. 59-78

ŽGANEC, N., LAKLIJA, M., MILIĆ BABIĆ, M. ACCESS TO SOCIAL.
Disabilities in Croatia and the Member States of the European Union). Društvena istraživanja, 21 (1): 79-100.

Ministry of Health and Social Welfare (2009), Annual Statistical Report on the Applied Social Welfare Rights, Legal Protection of Children, Youth, Marriage, Family and Persons Deprived of Working Ability, and Protection of Physically or Mentally Challenged Persons in the Republic of Croatia in 2008, Zagreb.

Ministry of Science, Education and Sport (2005), Education Sector Development Plan 2005-2010, Zagreb.

Ministry of Science, Education and Sport (2006), Primary School Curriculum, Zagreb.

Ministry of Science, Education and Sport (2008), National Pedagogical Standards for Primary Education System, Zagreb.

Ministry of Science, Education and Sport (2008), Development Strategy of the Vocational Education System in the Republic of Croatia 2008-2013, Zagreb.

Munday, B. (2010.), Integrated Social Services in Europe, Zagreb, Pragma.

National Strategy of Equalization of Opportunities for Persons with Disabilities 2007-2015, Official Gazette No. 63/07.

National Development Strategy for Health Care 2006-2011, Official Gazette No. 72/06.

Pearson, M. and Martin, J. P. (2005), Should We Extend the Role of Private Social Expenditure?, OECD Social, Employment and Migration Working Papers.

Pension Insurance Act. Official Gazette No. 102/98, 71/99, 127/00, 59/01, 109/01, 147/02, 117/03, 30/04, 177/04, 92/05, 43/07, 79/07, 35/08.

Potočnjak, Ž. and Vukorepa, I. (2007), Zakon o socijalnoj skrbi (Social Welfare Act), unofficial final draft, Zagreb, Official Gazette.

Primary and Secondary Education Act. Official Gazette No. 87/08.

Puljiz, V. (2004), Socijalna prava i socijalni razvoj Republike Hrvatske (Social Rights and Social Development of the Republic of Croatia). Revija za socijalnu politiku, 11 (1): 3-20. doi:10.3935/rsp.v11i1.65

Puljiz, V. (2007), Hrvatski mirovinski sustav: korijeni, evolucija i perspektive (The Croatian Pension System: Origins, Evolution and Perspectives). Revija za socijalnu politiku, 14 (2): 163-192. doi:10.3935/rsp. v14i2.698

Puljiz, V. and Žganec, N. (2002), Sustav socijalne pomoći i socijalne skrbi: mirovinski sustav i socijalna skrb (The Social Assistance and Social Welfare Pension System and Social Welfare), Zagreb, Ured za strategiju razvitka Republike Hrvatske.

Puljiz, V., Bežovan, G., Šućur, Z. and Zrinščak, S. (2005), Socijalna politika (Social Policy), Zagreb, Udžbenici Pravnog fakulteta u Zagrebu.

Rules on Rights, Conditions and Realization of Rights Arising from Compulsory Health Insurance. Official Gazette No. 4/94, 31/95, 57/96, 71/96, 108/96, 79/97.

Sajo, A. (2005), Social Rights: A Wide Agenda. European Constitutional Law Review, 1: 38-43. 
DRUŠ. ISTRAŽ. ZAGREB GOD. 21 (2012)

BR. 1 (115),

STR. $59-78$

ŽGANEC, N., LAKLIJA, M., MILIĆ BABIĆ, M. ACCESS TO SOCIAL..
Sjoberg, O. (1998), Paying for Social Rights. Journal of Social Policy, 28 (2): 275-297.

The Constitution of the Republic of Croatia, Official Gazette No. 55/2001. Učur, M. (2000), Socijalno pravo (Social Legislation), Zagreb, Informator. UNDP (2007), Human Development Report, Croatia 2006 Unplugged: Faces of Social Exclusion in Croatia, Zagreb, UNDP.

Vocational Education Act. Official Gazette No. 30/09.

Zrinščak, S. (2007), Zdravstvena politika Hrvatske. U vrtlogu reformi i suvremenih društvenih izazova (The Croatian Health Policy. In the Whirlpool of Reforms and Contemporary Social Challenges). Revija za socijalnu politiku, 14 (2): 193-220. doi:10.3935/rsp.v14i2.697

\section{Pristup sociialnim pravima i osobe s invaliditetom}

Nino ŽGANEC, Maja LAKLIJA, Marina MILIĆ BABIĆ Pravni fakultet, Zagreb

Pitanje pristupanja socijalnim pravima osoba s invaliditetom dio je širega područja reguliranja socijalnih prava $u$ suvremenom svijetu. $U$ zadnjih pedesetak godina obilieženo je znatnim napretkom na planu uvođenja socijalnih prava ne samo kao mogućnosti i intencije nego i kao stvarnoga doprinosa podizanju kvalitete života. Ciljevi rada jesu: analizirati postojeću situaciju na planu pravne regulative koja se odnosi na priznavanje socijalnih prava osoba s invaliditetom $\cup \mathrm{RH}$, uključujući neke elemente funkcioniranja sustava nadležnih za pristupanje socijalnim pravima osoba s invaliditetom; prikazati neka obiliežja provedenih reformi unutar najvažnijih "socijalnih sustava" u RH (socijalne skrbi, obrazovanja, zdravstva, mirovinskoga sustava i sustava zapošljavanja), utvrditi razinu percipirane pristupačnosti nekim socijalnim pravima od strane korisnika te iskazane potrebe za pojedinim oblicima socijalnih prava. Prikazani rezultati provedenog istraživanja pri tome ilustrativno upućuju na neke tendencije, ali i moguće probleme s kojima se osobe s invaliditetom susreću prilikom pristupanja ili pokušaja pristupanja pojedinim socijalnim pravima.

Ključne riječi: socijalna prava, osobe s invaliditetom, socijalna politika, pristupanje socijalnim pravima 